$$
\begin{aligned}
& \text { PNAAX-043 } \\
& \text { IAn }=49984
\end{aligned}
$$

\title{
RURAL WOMEN AND STATE: POLICY: THE LATIN AMERICAN AGRARIAN REFORM EXPERIENCE
}

\author{
by \\ Carmen Diana Deere \\ University of Massachusetts \\ Workirig Paper \#81 \\ March 1985
}

\begin{abstract}
This review of thirteen Latin American agrarian reforms shows that most have directly benefited only men. It is argued that this is largely because of the common designation of "households" as the beneficiaries of an agrarian reform and the subsequent incorporation of only male household heads to the new agrarian reform structures. It is shown that a necessary, but not sufficient, condition for rural women to be benefited on par with men is that they too be designated as beneficiaries. Women as well as men must be given access to land or the opportunity to participate within the agrarian cunperatives or state farms promoted by an agrarian reform. This comparative analysis of the Latin American agrarian reform demonstrates that this has rappened only in countries where the incorporation of rural women to the reform is an explicito objective of state policy.
\end{abstract}

About the Author: Carmen Diana Deere is an Associate Professor of Economics at the Universicy of Massachusetts, Amherst. She received her Ph.D. in Agricultural Economics at the University of California, Berkeley in 1978 . Dr. Deere's initial field research was on rural women, peasant househulds and agricultural development in Peru; subsequently, she has collaborated on national-level studies of this topic in Colombia, Nicaragua and the Dominican Republic. Among her publications are La Mujer en las Cooperativas Ayropecuarias en Nicaragua (with CIERA Rural Women's Research Group, Managuc, 1984); Women in Andean Agriculture: Peasant Production and Rural Wage Employment in Colombia and Perul (with Magdalena Lecn de Leal, ILO, 1982) and Mujer y Capitalismo Agraric (with ACEP Rural Women's Research Group, Bogota, 1980). Her research on Latin American agrarian reforms, agricultural policy and peasant household economics has been published in The American Journal of Agricultural Economics, The Cambridge Journal of Economics, Signs: Development and Change, The Journal of Peasant Studies, Economic Developmint and Cultural Change, among other journals. 
RURAL WOMEN AND STATE POLICY: THE LATIN AMERICAN AGRARIAN REFORM EXPERIENCE 1

In Latin America agrarian reform has been the major state initiative in agricultural development and rural income redistribution over the list severai decades. In some countries, agrarian reform fundamentally altered rural class structure and the national distribution of wealth and power. In other countries, efforts at reform were minimal, sometimes only involving colonization or resettlement schemes. Whatever the form or scale, each agrarian reform has involved state intervention in the redistribution of land to formerly landless or land-poor households.

The impact of an agrarian reform on rural women depends upon the class position of each wornan's household, and whether that class, or segment of class, is a beneficiary of the reform. The broader the reform's redistributionary thrust, the more women it should potentialiy benefit. It cannot, however, be assumed that the impact of an agrarian reform on rural households is gender neutral. An increase in the household's access to land or employment or in its level of income does not necessarily mean a positive change in women's socio-economic position. Processes of social change have complex economic, political, and ideological effects which may alter the social status of rural women as well as their position relative to men.

The central thesis of this paper is that most Latin American agrarian reforms have directly benefited only men. It is argued that this is largely because "households" are designated as the beneficiaries of an agrarian reform but only male household heads are incorporated into the new agrarian reform structures. It is shown here that a necessary, but not sufficient, condition for rural women to be benefited on par with men is that they too be designated as beneficiaries. Women as well as men must be given access to land or the opportunity to participate in the agrarian cooperatives or state iarms promoted by an agrarian reform. A comparative analys is of the Latir American agrarian reforms demonstrates that this has happened only in countries where the incorporation of rural women to the reform is an explicit objective of state policy.

This paper first presents a brief overview of thirteen Latin American agrarian reforms as well as the available gender-disaggregated data on agrarian reform beneficiaries. The following section presents an analysis of the mechanisms that have led to the exclusion of women among the beneficiaries of the agrarian reforms. It is argued that these mechanisms of exclusion are legal and structural as well as ideological. The two agrarian reform processes that have resulted in significant female participation--Cuban and Nicaraguan--are then examined. These cases illustrate how an explicit state folicy favoring the incorporation of rural. women is a necessary precondition for their participation. The next section considers why it is important, both for social equity and successful cooperative development, for women to be included as reform beneficiaries. The final section considers the barriers to women's effective participation as cooperative members. 


\section{AN OVERVIEW OF THE LP.TIN AMERICAN AGRARIAN REFORMS}

To establish the context for the subsequent analysis, this section presents a brief overview of the principal features of thirteen Latin American agrarian reforms. No attempt is made to analyze the efficacy of "ch of the agrarian reforms with respect to either its own goals or its tual impact upon the beneficiaries. Summarized in Table 1 is the year in lich the agrarian reforms were initiated or subsequently modified, the most ecent available estimate of beneficiaries as well as the proportion of rural households they represent, and the predominant form of tenure and productive organization in the reformed sector.

The potential redistributionary impact of an agrarian reform largely reflects the policical project that the reform represents.? The first three agrarian reforms carried out in Latin America, those of Mexico, Bolivia, and Cuba, were the product of social revolutions. Through the agrarian reforms, the traditional hacienda was virtually eliminated and a major redistribution of landed property took place in favor of a significant proportion of the rural population. 3

These three reforms differ, however, with respect to forms of tenancy and the organization of production in the reformed sector. The thrust of the Mexican agrarian reform was to constitute the ejido, a form of communal based property with production carried out either collectively or individually. The Bolivian agrarian reform favored the creation of individual private holdings. While the Cuban agrarian reform also had a significant "land to the tiller" thrust (every tenant, sharecropper and squatter was given ownership of the land cultivated), the bulk of the expropriated land went to constitute state farms. 4 Oniy in the mid-1970s was emphasis placed on the promotion of production cooperatives based on peasants pooling their individual roldings.

The agrarian reforms initiated in the 1960s represent the "Alliance for Progress" agrarian reforms. United States development assistance in the 1960 s was contingent on the Latin American countries instituting agrarian reforms. United States policy clearly recognized that, if revolutionary social change was to be avoided in the Americas, the pressing issues of rural inequality and poverty had to be addressed.

Launched in the wake of the Cuban revolution, the Alliance for Progress agrarian reforms aimed both at containing the peasantry as a potential revolutionary force and at breaking the power of the Latin American landed elite. The traditional landowning class was viewed as an impediment to development: and its hold on political power as a barrier to modernization. Moreover, it was argued, the redistribution of land would not only statisfy the peasantry's potentially revolutiona femands, but it would also spur growth by putting land into the hands of those who would work it most intensively. The higher incomes of these people would lead, in turn, to an enlargement of the internal market. A broader internal market would stimulate investment and hence the overall process of growth. Agrarian 
reform was thus the ideal mechanism both to contain the peasantry and to establish the preconditions for successful capitalist development.

Nonetheless, agrarian reform efforts in many Latin American countries were minimal, although agrarian reform laws were on the books. Considered in this analysis are only those countries where relatively serious attempts at reform were made. Of the agrarian reforms initiated under the Alliance for Progress, only those in Peru, Chile, and Veriezuela reached a significant number of beneficiaries. In the case of Peru and Chile, this only happened after the initial Alliance for Progress reforms were modified and implemented by more progressive governments, the Allende government in Chile (from 1970 to 1973) and the revolutionary military regime in Peru (from 1969 to 1978$)$.

ihe Alliance for Progress agrarian reforms generally favored the creation of individual private property, as Table 1 shows. Often this was accompanied by the organization of credit and service or marketing cooperatives among individual producers. In the 1970s, a number of countries gave priority to the organization of production cooperatives (based on collective or group farming), such as the asentamientos in Honduras or the empresas comunitarias campesinas of Colombia. The Allende reform in Chile and that of the Peruvian military favored collective forms of production, although in the latter case some land was also distributed individually.

The agrarian reform initiatives of the eighties are the product of the revolutionary upheaval in Central America. The Nicaraguan and Salvadoran agririan reforms represent quite different political projects. The $N$ icaraguan agrarian reform is being carried out in the context of revolutionary transformation, in the tradition of the first three Latin Anerican agrarian reforms. Within the reformed sector, equal priority has been given to the constitution of state farms, production cooperatives, and individual producers grouped in credit and service cooperatives (Deere, Marchetti, and Reinhardt, 1984). In contrast, as a political project, the Salvadoran agrarian reform is being carried out in the legacy of the Alliance for Progress. Its primary intent is to contain the peasantry as a revolutionary rorce (Deere 1982a; 1984). The reformed sector includes both production cooperatives and a "land to the tiller" program.

All except the latter two agrarian reforms were initiated before feminism became an international force and women's participation in development, a development concern. Since 1973, the Percy Amendment to the U.S. Foreig! Assistance Act has required all U.S. financed development programs ic take into account their impact upon women. Moreover, since 1975 when the U.iv. Decade for Women was launched, many Latin American countries have created governmental women's commissions or bureaus to oversee scate policy with regard to women. To what extent have these efforts brought state policy to bear positively on the position of rural women within the context of Latiri American agrarian reforms? 
Agrarian Reform Beneficiaries According io Gender

The majority of Latin American agrarian reforms have not produced significant numbers of female beneficiaries nor even given attention to gender as a beneficiary category. As Table 2 shows, few Latin American countries report beneficiary data by sex. Even after a decade of "women in development" Efforts, the majority of countries still find it sufficient to publish beneficiary data according to the number of households or families benefited. For example, in the recent Salvadoran agrarian reform, potential beneficiaries applying for land under decree 207, (the Land to the Tiller program) are not asked their sex. 5 The only country for which complete gender-disaggregated data on agririan reform beneficiaries is available is menduras. ${ }^{\text {Data for Cuba and Nicaragua refer only to cooperative }}$

The available national-level data suggest that only in cuba do women represent a significant number of current agrarian reform beileficiaries. Women constitute $26 \%$ of the 78,000 members of the country's 1,400 production cooperatives (Collins, Benjamin, and Scott 1984: chpt. XIII). The available data on the Cuban state farms also suggest that women have been incorporated a's wage workers in significant numbers on the state farms. By 1968, 44,000 women were employed as permanent workers on the state farms, and in the mid-1970s women represented $53 \%$ of the permanent workers in the state tobacco industry, $41 \%$ in the dairy industry, $19 \%$ in food processing, and $7 \%$ in the sligar industry (FMC 1975: 19).

The 1982 Nicaraguan Cooperative Census revealed that $20 \%$ of the production cooperatives and $60 \%$ of the credit and service cooperatives (based on individual private holdings) have at least one woman member. However, in 1982 women represented only $6 \%$ of the total cocperative membership of 64,891 . Rural women in Nicaragua fared somewhat better than their Honduran counterparts with women representing $3.8 \%$ of the agrarian
reform beneficiaries.

A 1971 survey of 83 Peruvian agrarian reform cooperatives found that, of 724 members interviewed, approximately 5\% were women (Buchler 1975). But as a national estimate, even this figure may be high because the survey excluded the important coastal agro-industrial sugar cooperatives where membership was almost exclusively male. Moreover, regional studies in northern Peru, in the cotton-producing zone of Piura (Fernandez 1982), and in the highland area of Cajamarca (Deere 1982b), found that women comprised only $2 \%$ of cooperative membership.

The available studies of the agrarian reform processes of other Latin American countries also suggest that the overwhelming majority of the agrarian reform beneficiaries have been men. uarrett reports that in Chile few women were beneficiaries of the agrarian reform (1982a, b). Similarly, in the Dominican Republic, the vast majority of beneficiaries have been men (Castro, Grullon, and Leon 1983: CEDEE 1983). In Colombia, women have been reported to be members of only 2 of 1,283 collective enterprises organized 
between 1973 and 1982 (Caro 1982: 196). No mention of women's participation could be found in the literature on the remaining agrarian reforms surveyed.

\section{MECHANISMS OF EXCLUSION}

The participation of rural women in the agricultural labor force in Latin America--both in peasant units of production and as seasonal wage. workers--has now been well documented in the literature.7 Yet, as the above data demonstrate, women have largely been excluded as agrarian reform beneficiaries. This section considers why and how women have been excluded from this major state initiative in rural areas.

The mechanisms of exclusion are legal, structural, and ideological. In most of the Latin American agrarian reforms, the legal criteria defining beneficiary status have served to sxclude the majority of rural women. This is often compounded by the structural characteristics of women's labor force participation. Moreover, ideological norms regarding the "proper" sexual division of labor often impede women from joining cooperatives even when it is legally possible.

Underlying almost all of the Latin American agrarian reforms has been the assumption that the rural household is the primary social unit to be benefited from the reform. But for purposes of implementation, in all except Cuba and Nicaragua, only one member of the household, the household head, has been officially designated the beneficiary. Hence, only the head of household has received land in his/her name or the right of membership in production cooperatives or credit and service cooperatives in the reformed sector.

Restricting beneficiaries to household heads only discriminates against women since throughout Latin America social custom dictates that if both an adult man and an adult woman reside in a household, the man is considered its head. Yet, in the majority of agrarian reforms examined, the beneficiary criteria either required or gave strong preference to heads of households. Even in those cases were beneficiaries were defined as individuals it was usually assumed, if not explicit, that on ?y one individual per household could be designated a beneficiary, and that was to be the household head. As a result, the only women who could potentially be reform beneficiaries were either widows or single mothers with no adult male living in the household.

A related, structural problem, is that many agrarian reforms have benefited only the permanent agricultural wage workers employed on estates at the moment of expropriation, excluding the often large seasonal labor force fron cooperative membership. In both Peru and Chile, for example, the permanent agricultural wage workers on the expropriated estates were generally men, although women were often an important component of the seasonal labor force. Fernandez (i982) shows how on the northern Peruvian cotton plantations, although women represented up to $40 \%$ of the temporary labor force, few women held permanent. jobs on the plantations, and as a result, women constituted only $2 \%$ of the cooperative membership. 
For Chile, Garrett's (1976) analysis demonstrates how the process of modernization of Chilean agriculture over the course of the twentieth century resulted in a sharp decrease in the number of permanent workers in agriculture. But women were displaced disproportionately from the estate's labor force as these estates were mechanized. At the time of the agrarian reform, these estates had few permanent workers relative to the total labor force employed during the year, and the permanent workers were largely (Garrett 1982b).

The inability of these agrarian reforms to benefit the vast majority of seasonal agricultural workers was certainly prejudicial to both men and women. But whereas men were found in both categories of workers, permanent and seasonal, the structural characteristics of women's labor force ivomen who were beneficiaries of the refont workers on the estates, and thus potential being household heads to , were then subject to the additional cricia of reduced their participation still further.

Many of the reforms instituted in the Alliance for Progress period, besides prioritizing landless workers and tenants, selected potential beneficiaries on the basis of a point system. In the case of Colombia, fc:example, the point system favored those whose history of residence or work was in or near the farm being redistributed, and those peasants with more education, larger family size, good reputations and farming experience (Edwards 1980: 59). Women would certainly be at a disadvantage compared to men in terins of educational attainment. Moreover, female heads of household might also suffer under the reputation criterion if nonconformity with the patriarchal nuclear family norm lowered their status in the eyes of the community. Women would also be disadvantaged by the farming experience criteria if socially, men are considered to be the agriculturalists and women, as unremunerated family labor, simply the "helpers."

Ideological norms governing the proper sexual division of labor--that a woman's place is in the home while a man's is in the fields--appear not only in the content of agrarian reform legislation, but also constitute a significant barrier to the incorporation of women as beneficiaries in reforms that explicitly provide for the inclusion of female-headed
households.

Inheritance provisions in the agrarian reform laws demonstrate that it was often explicitly assumed that beneficiaries would be male. Article 83 of the Venezuelan agrarian reform, for example, provides that in case of death or abandonment by the beneficiary: "the Institute will adjudicate the parcel to his wife or concubine, or in third place to the son..." (in Guerrero 1962). Similarly, the only mention of women in the costa Rican awner abandon law is the provision to give the land title, should the permanently with the title "to the wife or the other person(s) who has lived 
Only three agrarian reforms, those of Mexico, Bolivia and Honduras, made explicit provision to include female household heads as potential beneficiaries. The 1942 Mexican agrarian code provided for either single or widowed women to receive land in the ejido as long as they had dependent children. Nonetheless, the law also discriminated against women since men could apply for land irrespective of their family position if they were over 16 years of age or at any ige if they were married. Single women without dependents and married women could not (Chavez de velazquez 1960: 240). Moreover, if a female household head with land in the ejido married another ejido member she automatically lost her right to ejido land. While the apparent intention of this clause (article 171) was to prevent land concentration within the ejido, its consequence was to dispossess married women of land rights.

The revised 1971 Mexican agrarian reform law improved on the earlier agrarian code by stipulating that beneficiaries could be "male or female, above 16 years of age, or of any age if they have dependent children" (Anaya 1976: 75). Moreover, it allowed worien with land rights to preserve them if they married another ejido member (Alcerraca 1974: 77). However, Article 200 requires beneficiaries to be agriculturalists and implicit in the law is that women are not. The assumption that women's primary responsibility is to the home and children is clear in the provision requiring ejidatarios to work the land directly. Only a female household head is exempted from this provision because of being "constrained by domestic work and the attention to small children who depend upon her" (Anaya 1976: 77).

The 1952 Bolivian agrarian reform law considered eligible for land "those older than 18 who have been exploitcd (under feudal relations of production)...., those older than 14 and married, and widows with dependent children" (Article 78, in Jemio 1973: 42). While the rights of widows were protected in this law, it is unclear whether single mothers could ciaim beneficiary status. And once again, married women appear to be precluded from acquiring land through the reform. However, the 1965 Law of Indigenous Communities did provide for "either men or women" to receive land in indigenous cooperatives (Urquidi 1971: 233). The few references to women in the literature suggest that few married women or even female household heads have availed themselves of this opportunity (McEwen 1969: 88; Iriarte 1980: 86).

The 1962 Honduran agrarian reform law, like the 1942 Mexican agrarian code, guaranteed the rights of botn widows and single female household heads but discriminated against single women without dependents as compared to single men. In order to qualify as a beneficiary it was required to: "Be Honduran by birth, male, over 16 years of age if single or any age if married, or a single woman or widow if in charge of a family" (Article 68 in Escoto 1965: 46).

In terms of preference ordering, the Honduran law does give female household heads priority over male heads and single men, unless the men exploited land under indirect forms of tenancy, had been previously 
dispossessed of their land, or had access to insufficient land as established by the zone (Ibid.: 47). Apparently, the overwhelming number of rural men fell into one of these categories for Youssef and LeBel (1981: 57) report that "in existing asentamientos women have last priority in being allocated land; they follow male-headed households, and single males." Yet, in 1974, 18.7\% of Honduran rural households were headed by women (Callejas
1983 ).

An in-depth study of four Honduran asentamientos illustrated how the implementation of the law had resulted in the virtual exclusion of female household heads (Safilios-Rothschild 1983: 19). Women were simply not considered to be agriculturalists. While women's participation in certain agricultural tasks was recognized, women were not considered capable of carrying out the "heavier" agricultural tasks that required greater physical strength. Male cooperative members felt that women could join the cooperatives only if they had sons, and preferably adult sons, to replace them in agricultural field work. Thus, the predominant norms of the sexual division of labor served as a barrier to women's incorporation in the agrarian reform, although the law explicitly provided for at least female heads of household to be potential beneficiaries of the reform.

\section{THE PRECONDITIONS FOR FEMALE PARTICIPATION}

In only two countries, Cuba and Nicaragua, has neither sex nor kinship position been a legal barrier to the inclusion of women in the agrarian reform process. In both countries, not only female heads of household, but also wives and daughters, can qualify as agrarian reform cooperative members. Moreover, in both countries, the incorporation of rural women is an explicit state policy goal.

In terms of rural women's participation, the Cuban agrarian reform process began along a road similar to that just described. The numerically impcrtant small farm sector created through the first agrarian reform law (1959) was considered to benefit household units. The National Association of Small Producers (ANAP), the principal organization charged with developing credit and service cooperatives and other associations among private producers, was constituted by household heads who were primarily men. Within the state sector, the agricultural unions that were formed were also overwhelmingly' male since they organized the permanent workers on the former sugar and cattle estates who were generally men. Although the number of permanent workers within the state sector was steadily increased, particularly after the 1963 agrarian reform law was promulgated, few women were employed on a permanent basis until the late 1960s.

The development of an explicit state policy with regard to the incorporation of rural women into the agrarian reform process was a response to both ideological and economic considerations. As the Cuban revolution began to develop its explicitly socialist characier, the issue of equality, not just between social classes, but aiso between men and women, had to be addressed. Orawing on the Marxist classics, the cubans accepted the 
theoretical premise that women's equality with men required their incorporation of women into the social labor force (Engels 1975). The incorporation of women into productive labor was seen as a necessary step not only for women's own social development but also for the transformation of the social relations of Cuban society (Castro 1981; PCC 1976).

This theoretical position was complemented in the late 1960 s by the economic imperative of increasing rural women's agricultural participation. The expansion of sugar cane production in the late 1960s significantly increased the demand for temporary labor. It was at this time that a concrete policy to integrate rural women into the labor force took form, and it was largely the result of the joint efforts of ANAP and the Cuban Women's Federation (FMC). In 1966, these two mass organizations joined to promote what were known as the FMC-ANAP brigades of rural women (FMC 1975). At first consisting of volunteer labor, they provided the mechanism for thousands of rural women to participate in social production for the first time (Bengelsdorf and Hageman 1977).

These female brigades were responsible for solving the seasonal labor shortages within the state sector and on private farms. It was estimated that by the mid-i970s women constituted over half of the seasonal labor force for the sugar cane, coffee, tobacco and fruit narvesis (Fic 1975 ). An important change, which expiains the steady increase in women's participation, was that by tine mid-1970s brigade work was no longer unremunerated. The FMC was successful in assuring that women were paid a wage for their work and that they received the same pay as men for equal work. Moreover, in order to encourage women's participation in the brigades, it was necessary to attend to women's reproductive roles. The FMC played a central role in promoting the development of child care centers in the countryside as well as the expansion of communal eating facilities at rural work centers.

The organization of rural women by FMC-ANAP was not limited to women's role in the seasonal labor reserve. It also promoted the incorporation of woinen as permanent workers on the state farms and as members of the credit and service cooperatives of private producers. In the 1970s, eligibility for cooperative membership was ch.inged from household heads to individual membership for all adults in the farm household. The FMC-ANAP brigades became the channel for the provision of technical assistance specifically for women so that they could develop the general agronomic and veterinary knowledge required for modern farming as well as specific skills for their own income generating projects (FMC 1975). They also promoted women's participation in decision-making in the farm household and in the credit and service cooperatives.

The FMC-ANAP brigades proved an important mechanism for organizing rural women and, by taking into account their specific needs and interests as women, integrating them into the national project of revolutionary charige. This is seen in terms of the role that rural women have played in the development of production cooperatives in the post-1975 period (FMC 1975). In that year. production cooperatives for the first time received official 
endorsement; state incentives were given for private farmers to voluntarily constructing a new holdings. Among the incentives was the possibility of many women's domestic tasks. Of membership and guaranteed employment in thportance was women's right of noted earlier, women now constitute $26 \%$ of the production cooperatives. As

In contrast to the Cuban case, where women's participation in the agrarian reform evolved over the course of the revolution, the Nicaraguan from the beginning. In the incorporation of women among its objectives kinship position is a In the 1981 agrarian reform law, neitier sex nor And the incorporation of explicit objective detail women into the agricultural cooperatives is an II, Article 2). Moreover in the 1981 Agricultural Cooperative Law (Chpt. into the cooperatives under the legislation requires women to be integrated and duties. The agrarian the same conditions as men, with the same rights Guarantees of Nicaraguans (Decree the equality of the sexes before the 52, 1979, Article 3) which establishes by all means all obstacles that impede and requires the state "to remove their participation in the political, the equality of its citizens and country."

Interestingly, in a recent study of women's participation in the Nicaraguan agrarian reform cooperatives it was found that many women did not await the passage of the agrarian reform legislation to begin joining the agricultural cooperatives (CIERP. 1984: chpt. 3). In the majority of cases 1979-1981 period. This reflects the as they were being constituted in the Nicaragua in the struggle that the important participation of women in that they "had won their right" to participate Somoza dictatorship; women felt Nonetheless, the study also showed armament in breaking down truditional that the law has been an important labor and male resistance to female views of the proper sexual division of

Even in a revolutionary setting, cooperatives are still organized witiout taking the possible participation of women into account. In were not interested in cooneratives, members often asserted that women agricultural work. In fact, in seratives because they did not perform interest in joining these cooperatives l cases women had demonstrated their (Deere 1983; CIERA 1984). As is thes but the male rilembers had ignored them 1983), male cooperative members the case in Honduras (Safilios-Rothschild members since they did not believe that often reluctant tn admit women as number of agriculturdl tasks. with women members revealed that womeless, case studies of ten cooperatives on par with the men. Moreover, men in articipated in productive activities much more pusitive about women's participation and with women members were cooperatives without women members. This hion and contribution than men in (Safilius-Rothschild 1983). It suggests that a posive reported in Honduras 
regard to women creates the necessary preconditions for women's participation and that giving women a chance to participate has important effects on ideological norms regarding the gender division of labor. This, as will be discussed later, has important implications for successful cooperative development.

The importance of a clear and vigorous state policy with respect to women's participation is illustrated by a contrasting example to the Cuban and Nicaraguan cases, that of the Chilean agrarian reform. Upon taking office in 1970, the Allende government broadened the criteria for defining beneficiaries because redistribution of access to resources as well as the generation of increased employment opportunities in the countryside were explicit policy goals of the Popular Unity government. The imbalance between the situation of permanent and temporary workers on the asentamientos (who were respectively, the members and non-meribers) was seen to be particularly problematic, so the asentamientos were reorganized to facilitate the incorporation of temporary workers.

In this broadening of the potential beneficiaries of the reform, the legal-structural impediments to women's participation within the new agrarian reform structures were eliminated (Garrett 1982a,b). Neither sex nor marital status were to constitute criteria for membership, and al? individuals over 18 years of age were eligible to become members of the general assembly of the new Centers of Agrarian Reform (the CERA's). As Garrett shows, the conditions were in place for women to be able to participate in the agrarian reform, but the new regulations did not result in the incorporation of a significant number of rural women. This was partly because of the lack of clarity within the Popular Unity government as to what should be the role of women in the agrarian reform.

Garrett's analysis shows how ideological and political factors worked against women's incorporation into the reformed sector even after their participation was made legally possible. She argues that women's participation in the CERA's was resisted by both men and women. This refilected the conservative influence of what was the strongest women's organization in the countryside, the Centros de Madres (mother's centers) organized by the Christian Democractic party under the Frei administration. The centers focused on and promotea women's domestic ro'? much as they did in the Dominican Republic, Honduras and Venezuela. They gave little attention to women's role in production or to social problems since these were considered inappropriate activities for women. But they did provide rural women with a social outlet that drew them out of their homes into a forum where they could discuss their own everyday problems. At their heyday, the centers had some 10,500 members in the Chilean countryside.

The centers were apparently never integrated into the structure of the asentamientos. The Popular Unity government recognized this as a problem and proposed to organize rural women into Social Welfare Committees linked to each CERA. The Social welfare Committees were intended to find collective solutions to social problems. But as Garrett illustrates, 
neither men nor women were in agreement that women should be concerned with problems that went beyond their own domestic units. Few rural women joined the Social Welfare Committees of their own volition, and the Allende government neither had nor directed the human resources required to organize rural women along lines different from those that had been traditionally successful. This was partly because of the difficult political conjuncture with which the Allende government was faced by 1973, but it also reflects the lack of a clear state policy with regard to the incorporation of women. In other words, the explicit absence of a state policy vis-a-vis women's participation in the agrarian reform was a source of confusion and acted as a barrier to women's actual incorporation.

\section{THE IMPORTANCE OF INCORPORATING WOMEN}

It is important for women as well as men to be included among the direct beneficiaries of an agrarian reform to ensure both social equity grounds and the success of cooperative development. The exclusion of women not only has high costs for women, in that their position can be harmed both relative to men's and absolutely, it also has costs for cooperative and rural development programs. And if the goal of an agrarian reform is to foster a process of social transformation, as was considered the case in various of these reforms, then the exclusion of one social group on the basis of gender or family position certainly limits the breadth and depth of the reform process.

Social equity criteria would require that, at the very least, if both men and women are permanent agricultural workers, both be entitled to become beneficiaries of an agrarian reform. An example from the dairy region of northern Peru, the province of Cajamarca, is illustrative of the discriminatory nature of constituting production cooperatives on the basis of only those permanent workers who are household heads (Deere 1977). In this region, women made up from $30 \%$ to $50 \%$ of the permanent workers on the dairy farms since milking (which is still done manually) was considered a strictly female task. But of the 15 agrarian reform production cooperatives in the province, only five had female members and, overall, women constituted only $2 \%$ of the total cooperative membership. The women workers were excluded from cooperative membership primarily because they did not qualify as household heads becalise of their kin relationship to a male permanent worker on the farm. The result was that the only women who became cooperative members were widows or separated women who did not live with an adult man and who had children under 18 years of age.

If a goal of state policy in creating production cooperatives is to allow the participation of workers in the decisions concerning the ir labor process and in the allocation of the surplus which they produce, the exclusion of one group from membership on the basis of sex and kinship, is, at best, discriminatory. At worst, it creates the conditions internal to the cooperative for the exploitation of one social group by another.

This is also the case in the relationship between permanent workers (the cooperative members) and temporary workers. In the Peruvian reform process, 
few temporary workers were incorpurated into the cooperatives; they were not covered by social benefits, and their wages were usually lower than those of the cooperative members. Fernandez (1982) and Chambeu (1981) report that, in the cooperatives in Piura and Cuzco that they studied, not only were the majority of women working on the cooperatives temporary workers, but the women earned wages lower than did the male temporary workers. Moreover, women's wages relative to both male temporary workers and the cooperative members declined over the reform period. In the case of the piura cotton cooperatives, work opportunities for women also declined over the reform period (Fernandez 1982). Since the women had been excluded from cooperative membership, they had no recourse in this deterioration in their economic position.

The only reference to womer's participation in the Ecuadorian agrarian reform is Article 8 of the 1973 Statutes of Production Cooperatives. The Statutes list as a condition for the official recognition of the cooperative that a cooperative employ outside labor only "occasionally... and then only when preference has been given to the wives and families of members" (In Redclift 1978: 154). The analys is of the fate of female temporary workers in Peru suggests how marginal this institutional recognition is to women's labor force participation.

Another way in which processes of agrarian reform may be harmfui to women is in terms of the changes introduced in traditional patterns of land rights. In most Andean highland areas, land inheritance has been bilateral. Women's ownership of land has assured them of participation in both agricultural decision-making and the allocation of household income. Land ownership has also given women a modicum of material security because they have not been totally dependent on their spouses. If a woman was abandoned or separated from her spouse, her inheritance assured her of a means of maintaining her family as single woinen.8 Not surprisingly, a woman's status within the household and community is closely related to her ownership of land.

The Peruvian agrarian reform process represented a real setback for rural women. While the objective of the reform had been to promote production cooperatives on the estates that were expropriated, in many cases this was impossible due to peasant resistance and, in the post-reform period following the election of Belaunde, these peasants received individual titles to their plots. But since only male household heads were designated the potential beneficiaries, the land titles issued by the reform agency generally have been given only to men.

It cannot be assumed that indirect participation in a reform process (through the head of household) is the equivalent of direct participation. The organization of credit and service cooperatives among independent producers on the basis of only male household heads may have important consequences for women's agricultural productivity. Providing technical assistance only to men will not necessarily result in women gaining access to the information or guarantee that they will take it into account and 
put it into practice. For example, if women are traditionally charged with seed selection in the peasant household, it cannot be assumed that training men in the benefits of new varieties will result in the information being passed on to and accepted by the women.

A Nicaragua cooperative study found an impressive disparity in the level of technological knowledge of women members and women non-memb srs (CIERA 1984: Chpt. 5). Male cooperative members rarely shared with their non-member wives what they were learning. On one credit and service cooperative with a significant number of female members, one male member admitted to this author that he was worried that his non-member wife knew so little cornpared to tine female members because, if anything happened to him, she would take over management of the farm. But this reflection only took place because women had already been incorporated as cooperative members.

The 1979-83 Honduran National development plan appears laudatory in that it calls for the incorporation of 5,625 peasant women who are "direct or indirect" beneficiaries of the reform in activities leading to the economic diversification of the cooperatives (Honduras n.d.). But incorporating women as temporary wage workers or into special income generating projects does not necessarily lead to an improvement in their material well being or status. Without the status of cooperative mernbership, the women are assured neither control of the resources necessary to carry out complementary income generating activities (Garrett 1982b) nor participation in the decisions governing labor allucation, wages, or the surplus produced.

The 1971 Mexican law is also unusual in providing women who are non-ejido members access to one parcel of land for collective agroindustrial activities. Article 103 indicates that the land should be of the best quality and adjacent to the urbanized area with "child care centers, centers of sewing and education, nixtamal mills, and in general, all those installations destined specifically to be at the service and protection of the peasant woman" (Anaya 1976: 79). Whether these actually materialized is unknown. While it is commendable that the law gives some attention to women, it must be kept in mind that these rights are not the equivalent of having access to laid in one's own name or the right to participate in the decisions of the ejido.

Moreover, all too often these special projects aimed at women fail to recognize women's role as agricultural producer and serve to reproduce the idealized sexual division of labor with women as housewives and nothers. This has been the case not only in Honduras and Mexico, but also in Chile, Venezuela, and the Dominican Republic. Since the $1960 \mathrm{~s}$ in all of these countries, the wives of beneficiaries have been organized into "mother's clubs" or "mother's centers" where they are taught skills that are an extension of their domestic roles: cooking; sewing; flower arrangement; 1983). (Callejas 1983; Garrett 1982a,b; Soto 1978; CEDEE 1983; Castro et al. 
When an agrarian reform directs state efforts and resources to benefit one group of the population through access to land, credit, technical assistance, marketing charnels, etc., it is concentrating resources on only one specific group with socio-economic consequences for those who are excluded. It cannot be assumed that, by benefiting the male head of household, all household members will be benefited as well. Neither can it be assurned that, by organizing women into their own gender-specific activities, women will not lase out relative to men. The household is not gender neutral and neither are the effects of a process of state intervention.

Women as a Positive Force for Cooperative Development

The Nicaraguan experience thus far seems to show that the incorporation of women to the agrarian cooperatives has been beneficial for cooperative development. In the cooperatives with women members, women are considered to be excellent agricultural workers, and they are a force of cohesion and stability in the cooperatives. In one study, it was found, for example, that proportionately more men than wonen had left the production cooperatives for reasons of personal feuds with other cooperative members or because they did not like collective work. The relatively few women who had abandoned the cooperatives were more likely to have left because of fanily problems such as jealous husbands (Deere 1983).

In the few cooperative enterprises with women members in Colombia, women have also been noted to be a force of stability and cohesion. Lodono (1975: 144) reports that "ine integration of the woman and family has proven itself of real influence in the cohesiveness of the empresa. When the family lives on empresa land, when the woman participates in the assemblies and in the committees, with voice and even with vote, when she is listened to on problems of management and administration, the whole group feels itself more rooted in the empresa."

In Nicaragua, as in Cuba, women appear to be a favorable force behind collectivizaticn. In Nicaragua, the strong commitment of the women members of the production cooperatives to collective work is in many ways explained by the history of discrimination against women in rural Nicaragua. The majority of wonen members were previously landless wage workers and, as women, they had fewer agricultural employment opportunities open to them than did the men. Moreover, in the past, women were always paid less than men, even for the same tasks. Today they earn the same wage as men irrespective of the task performed, and the cooperatives offer them security of employment for the first time (Ibid.).

The discriminalion women have traditionally faced also explains why women seem less prone than men to dream of their own private plots, and why, in some cases, women have voluntarily pooled their private land parcels to form a production cooperative. Because women had not been taken seriously as agricultural producers in the past, they had been excluded from access to credit and technical assistance. Moreover, female household heads often 
found it more difficult than men to acquire sufficient labor for certain agricultural tasks and to acquire male labor for the key "male only" tasks. pooling their land offers them the security of permanent employment and

In the Cuban case, female support for collectivization seems to be particularly tied to the advantages offered women in the realm of reproduction. Up through the 1970s, Cuban policy greatly favored workers on state farms through the development of what are known as the agricultural communities. The new conmunities offer modern housing, guaranteeing the provision of potable water, sanitation and electricity; moreover, they offer health centers, schools and day care centers, communal eating facilities, and stores provisioned with basic necessities. The principal change in policy with respect to the formation of production cooperatives was that, for the first time, the facilities for the construction of similar agricultural communities would be offered to farmers that pooled their land to form such a cooperative. The state would provide the materials anc technical assistance if the new cooperative members provided the labor.

The rural women interviewed by this author in 1981 were quite clear as to the benefits offered them by the new agricultural communities. What they all stressed was the increase in their families' standard of living and well being and the importance of having convenient child care. Moreover, the improved housing greatly reduced the drudgery of housewor!. It was quite clear that women's enthusiasm for the new agricultural communities had been a central factor in the successful development of the production cooperatives and that this enthusiasm was tied to the benefits offered women with respect to their responsibility for household reproduction.

Both the Nicaraguan and Cuban experiences demonstrate that social equity and successful cooperative development are not a trade-off. Moreover, these positive experiences suggest the costs of excluding women in the other Latin American agrarian reforms.

THE PROBLEM OF ASSURING WOMEN'S EFFECTIVE PARTICIPATION AS COOPERATIVE
MEMBERS.

The analysis of women's participation in the Latin American agrarian reforms has demonstrated the importance of an explicit state policy with regard to the inclusion of women as reform bcneficiaries. Legal reforms, however, only clear the way for women to claim beneficiary status. They are participation within a sufficient condition to ensure women's effective that rural women have reformed sector. In this section, the difficulties membership in the cooperatives are in exercising their full rights of to achieve full equality with men as amined. It is argued that, for women must also be given to the material cooperative members, state attenition subordination. 
A fairly common observation among those who have studied agrarian cooperatives with women members in Latin America is that, while women may participate in the productive activities of the cooperatives on par with men, they play a much reduced role with respect to cooperative decisionmaking. In the Peruvian cooperatives, female members usually attended cooperative meetings, but rarely did they actually participate in the discussions (Deere 1977; Fernandez 1982; Chambeu 1981).

Buchler (1975: 50) describes Peruvian women's participation as follows: "At the cooperative meeting the woman member is expected to be more reserved than the men. She usually sits on the floor in peasant society while the men take up any of the chairs available. Nevertheless, she can speak up when her interests are endangered. Her opinion will be listened to, but she seldom has much effect unless seconded by some important male leader."

Fernandez (1982) reports that, in northern Peru, women as well as men viewed women's lack of education as a central factor in their inability to participate as effective cooperative members. In rural Peru, illiteracy falls disproportionately upon women. The men reportedly viewed this as the principal reason women were unqualified to participate in decisions regarding the cooperative. The women viewed their illiteracy as the primary reason that men showed little respect for their views and they were afraid to speak at cooperative meetings. But it should also be noted that women constitute a minority of the membership of these cocperatives, and the sheer power of numbers might explain the women's reluctance to participate in the
meetings.

In the Nicaraguan cooperatives, the women members were also less likely than the men to offer their opinions in cooperative meetings and to be actively involved in the affairs of the cooperative (CIERA 1984). The relatively lower degree of education of the women as compared to the men was often cited as the reason for women's lesser participation in cooperative decision-making. While the majority of women members in Nicaragua are literate (most as a result of the 1980 literacy campaign), few have confidence in their ability to deal with the complex affairs of cooperative management. Moreover, household responsibilities often limit their ability to participate in the on-going adult education program, thereby reproducing the ineouality in functional literacy levels.

The responsibility of women for domestic chores and child care limits their ability to participate as effective cooperative members in other wys. The working day of women members is much longer than that of the ir male counterparts. The women members commonly spend two to three hours in domestic labor before going out to the fields and, after a six to eight hour day working for the cooperative, return home to resume the ir domestic tasks. In contrast, the men usually socialize with the other male cooperative members after work, time often spent discussing cooperative business (CIERA 1984). 
The problem of "the double day" also affects the ability of women to meet their full membership responsibilities in the cooperatives. It also Chambeu (1981) reports that in poor retention rate of women members. male members felt that women in a Cuzco cuoperative that she studied, the cooperative since they often could serious about their commitment to the problems. If the children are sick, it is usua full day because of family to care for them. Rather than viewing this response in this cooperative in 1980 was this as a social problem, the women as members. The cooperative had already vote not to accept any more respect to men's : contrary to Peruvian minimum wage provisions s wages with impediments to participation, it is not surprizinge provisions. With these eight women members resigned, being replaced by their husbands 9 the original

Biological reproduction is another factor that sometimes places women cooperative members at a disadvantage. In few countries have cooperatives made provisions for paid maternity leave. Only in Cuba are women cooperative members covered by a national social security system that cooperative members woman worker's right to covered by the labor legislation that stipulated a individual cooperative. unjust for the cooperative to bear suoperative leadership considered it Cajamarca, a wonan who had demanded such a cost. On one cooperative, in was pressured to resign. She was subsequent right to paid naternity leave by her husband.

The responsibility of women for domestic labor and child care, as well as their relatively lower educational attainment and lack of authority over leadership positions in the cooperatives cited for women's not being elected to have been reported of the cooperatives. In Peru, only a handful of cases Chambeu (1981) reports the negatives with women officers (Bronstein 1982). cooperative that elected a ghort-lived experience of a Cuzco family responsibilities, the woman was unable to offectiven. Because of work that she had been assigned, confirming to effectively carry out the that women are not suited for leadership the view of the majority of men suggests that women's responsibilities in the positions. This experience barrier to their effective participation within household do constitute a must be directly addressed.

In Nicaragua, the data on women in cooperative leadership positions is more encouraging. A study of ten cooperatives with women members found that a woman was a cooperative officer in half of them (CIERA 1984). In most cases a woman had been elected to a leadership position as a result of an explicit concensus in the cooperative that the women members should have a actively promoted by the peasant's orgact of the explicit state policy, participation within the cooperatives. 
While gender-disaggregated data on cooperative leadership is not available for Cuba, the data on women in leadership positions in the peasant organization responsible for organizing the production cooperatives is quite favorable. In the mid-1970s, 16\% of the local leadership positions in ANAP were held by women (PCC 1976: 30).

Of all the Latin American agrarian reforms, the Cuban agrarian reform process is the one in which women have made the most impressive gains. But even these women still do not participate in production on equal terms with men (Croll 1979). Women are still disproportionately represented among the temporary workers who provide seasonal labor to the state farms and to the production cooperatives. Collins, Benjamin, and Scott (1984) also report that women's earnings on the cooperatives are substantially lower than men's. They note that there is still a marked sexual division of labor in productive tasks, and men's tasks are often better paid. Further, women cooperative members often work fewer days and fewer hours per day than men because of household responsibilities.

Cuban state policy has recognized the burden of the double day for women and its role in limiting women's full participation in production. The Family Law, promulgated in 1975, requires men to share equally in child rearing and in domestic maintenance tasks when the wife works in social production (see Stone 1981: Appendix 2).

This is a most innovative step in social policy. Its importance lies in state recognition of the fact that women's participation in social production alone is not enough to guarantee women's equality with men as long as women alone carry the burden for reproduction. If domestic labor cannot be fully socialized, the only alternative, if women's equality is to be achieved, is for men to share the reproductive burden. While Cuban society has not yet eradicated the subordination of women, important legal and economic preconditions, necessary to achieve the goal of social equality, are in place.

\section{CONCLUSIONS}

This comparative analysis of the Latin American agrarian reform experience has demonstrated that processes of socio-economic change are not gender neutral. It cannot be assumed that state policies designed to benefit rural nouseholds will necessarily benefit the women in them.

Rural women in Latin America have not benefited from agrarian reform on par with men. Lack of attention to the incorporation of women as direct beneficiaries has resulted in women losing access to resources and/or being displaced from productive activities. The consequences are both economic-leading to lower female productivity or lower incomes--and social-- contributing to a decline in female status and well being. The lack of inclusion of women in new agrarian reform structures has also created new barriers to achieving male-female equality, barriers that serve to reproduce 
women's subordination. Moreover, the lack of female participation has also lead to less successful processes of cooperative development, agrarian reform, and certainly of social transformation.

This comparative analys is of agrarian reform processes suggests that how rural women fare in an agrarian reform is closely tied to state policy. The inclusion of women in a process of social-economic change does not happen automatically. At a minimum, it requires state attention to the legal and structural barriers that preclude female participation. As demonstrated, the criteria for selection of agrarian reform beneficiaries is most important in this regard. A crucial pre-condition for an egalitarian agrarian reform is that all adults in the targeted group be legally entitled

The right to acquire land in one's own name or the right of cooperative membership is a necessary but not sufficient condition for women to participate on par with men in an agrarian reform. State policy must also to want to participate, the incentive and support structure for women men, and to be able to overcome the possible resistance of domestic responsibilities and are important components of both the these compatible with productive work policies that enable women to the incentive and support structure. Other agrarian structures include a participate more effectively in the new leadership training

This comparative analysis of the Latin American agrarian reforms also suggests the important role that rural organizations can play in either promoting or discouraging women's participation in the new agrarian organizations provided experience is most instructive, for here the mass level processes of change. Moreover, the coordination tetween the local organization and the small farmers' organization proved effective in attention to the specific needs of women. 


\section{NOTES}

1. An earlier version of this paper was presented to the Conference on "After The Second Sex: New Directions," University of Pennsylvania, April, 1984. The author is grateful to Hannain Roditi for skillful research assistance.

2. An excellent class-analytic overview of the Latin American agrarian reforms is provided in de Janvry (1983: chpt. 6).

3. The short-lived Guatemalan agrarian reform also fits into this category. Between 1952-54, 33\% of the peasantry was beriefited through the reform (de Janvry 1983: Table 5.1); the reform was subsequently undone.

4. After the implementation of the Cuban 1963 agrarian reform 1aw, $63 \%$ of the cultivable land was in the state farm sector and $37 \%$ within the private, small farm sector (MacEwan 1981: chpts. 6, 8).

5. See Beneficiary Application Form, Appendix 3 in Simon, Stephens, and Diskin (1982). The Agency for International Development, currently funding this agrarian reform, informed the author that data according to the sex of beneficiaries was not available for either Phase I or Phase III of the reform. Nevertheless, compliance with the Percy Ammendment requires that all U.S. foreign assistance programs take into account the impact of such programs on women.

6. In both the Cuban and Nicaraguan reforms, land has been distributed in the form of individual private holdings to peasant households who have not necessarily joined cooperatives. Moreover, also excluded from this estimate are female permanent workers on the state farms. As a result, the available data underestimate the proportion of women benefited through the reform.

7. See Leon (1982) for a compilation of recent writings on women's agricultural participation throughout Latin America. A measure of women's agricultural participation in the Andean region is provided in Deere and Leon de Leal (1982).

8. Data for the Peruvian province of Cajamarca illustrate the importance that women have placed on owning land. In this area, many of the large estates were sub-divided by the landiord class in the 1950s and $1960 \mathrm{~s}$ and the core of the estates converted into modern dairy enterprises (Deere 1977). Peasant households were given the opportunity to purchase the more marginal hacienda lands. Through an allalysis of the property registers of the province, I found that $40 \%$ of these land sales to the peasantry were registered in the name cf both husband and wife. In the remai... $60 \%$, land was registered in tine narie of only one person, but jus as many women as men purchased land in their own names. 
9. Structural problems, related to beneficiary criteria, are also important in explaining why the few women cooperative members in Peru have gradually been displaced. In one of the Peruvian dairy cooperatives studied by this author, the majority of women members in 1976 had been young single women who subsequently married in the 1976-1982 period. Since, according to cooperative laws, only the head of household could be a member of the cooperative, as these young women married they ceded their positions to their husbands. This was also the only way that their husband could obtain full time employment in the countryside. Chambeu (1981) reports a similar phenomenon in the Cuzco region.

10. A few Latin American countries have recently begur to take into account women's role as agricultural producer ir. designing agricultural sector strategies. For example, in Colombia, a recent policy document recognized the importance of removing barriers with respect to women's access to land; moreover, it recommended that state agricultural resources be directed specifically to rural women (Colombia 1984). 
Table 1. The Latin American Agrarian Reforms

\begin{tabular}{|c|c|c|c|c|}
\hline COUNTRY & YEAR & BENEFICIARIES & $\begin{array}{l}\% \text { RURAL } \\
\text { HUUSEHOLOS } \\
\end{array}$ & $\begin{array}{l}\text { ORGANIZATION } \\
\text { OF PROOUCTION }\end{array}$ \\
\hline Mexico & $\begin{array}{l}1917 \\
1971\end{array}$ & $\begin{array}{l}2,890,000 \\
(1971)\end{array}$ & $69 \%$ & ejidos \\
\hline Bolivia & 1952 & $\begin{array}{l}217,000 \\
(1970)\end{array}$ & $33 \%$ & individual \\
\hline Cuba & $\begin{array}{l}1959 \\
1963\end{array}$ & $\begin{array}{l}260,000 \\
(1963)\end{array}$ & $70 \%$ & $\begin{array}{l}\text { state, indiv., } \\
\& \text { prod. coops. }\end{array}$ \\
\hline Venezuela & 1960 & $\begin{array}{l}107,523 \\
(1970)\end{array}$ & $17 \%$ & $\begin{array}{l}\text { individual \& } \\
\text { prod. coops. }\end{array}$ \\
\hline Colombia & $\begin{array}{l}1961 \\
1973\end{array}$ & $\begin{array}{l}135,000 \\
(1975)\end{array}$ & $10 \%$ & $\begin{array}{l}\text { individual \& } \\
\text { prod. coops. }\end{array}$ \\
\hline Costa Rica & 1961 & $\begin{array}{l}18,078 \\
(1975)\end{array}$ & $9 \%$ & individual \\
\hline Honduras & $\begin{array}{l}1962 \\
1975\end{array}$ & $\begin{array}{l}33,203 \\
(1978)\end{array}$ & $8 \%$ & $\begin{array}{l}\text { individual \& } \\
\text { prod. coops. }\end{array}$ \\
\hline $\begin{array}{l}\text { Dominican } \\
\text { Republic }\end{array}$ & 1962 & $\begin{array}{l}11,000 \\
(1970)\end{array}$ & $3 \%$ & $\begin{array}{l}\text { individual \& } \\
\text { some coops. }\end{array}$ \\
\hline Chile & $\begin{array}{l}1962 \\
1970\end{array}$ & $\begin{array}{l}58,170 \\
(1973)\end{array}$ & $20 \%$ & asentainientos \\
\hline Peru & $\begin{array}{l}1963 \\
1969\end{array}$ & $\begin{array}{l}359,600 \\
(1975)\end{array}$ & $37 \%$ & $\begin{array}{l}\text { prod. coops \& } \\
\text { some individual }\end{array}$ \\
\hline Ecuador & $\begin{array}{l}1964 \\
1973\end{array}$ & $\begin{array}{l}50,000 \\
(1972)\end{array}$ & $7 \%$ & $\begin{array}{l}\text { individual \& } \\
\text { some coops. }\end{array}$ \\
\hline Nicaragu. & $\begin{array}{l}1979 \\
1981\end{array}$ & $\begin{array}{l}72,072 \\
(1983)\end{array}$ & $30 \%$ & $\begin{array}{l}\text { state, prod. coops., } \\
\& \text { individuals }\end{array}$ \\
\hline El Salvador & 1980 & $\begin{array}{l}74,936 \\
(1983)\end{array}$ & $12 \%$ & $\begin{array}{l}\text { prod. coops. \& } \\
\text { individuals }\end{array}$ \\
\hline
\end{tabular}


SOURCES AND NOTES TO TABLE I:

Mexico: Manzanilla (1977); percent of rural households benefited based on estimated 4,210,877 rural households in 1971 .

Bolivia: Jemio (1973: 43, 73-74); based on estimated 668,597 rural households in 1970. In 1970, there were 587 production and marketing cooperatives in
existence with 25,009 members.

Cuba: Based on estimate of 110,000 new property owners as result of 1959 and 1963 laws, and permanent employment on state farms of 150,000 by 1963 (MacEwan, 1981: 53, 56). Mesa-Lago (1972: 49) reports a somewhat higher figure, 200,000 new property owners, by the end of the implementation of the 1963 agrarian reform. In 1983 there were 1,400 production cooperatives with 78,000 members (Collins, Benjamin, and Scott, 1984).

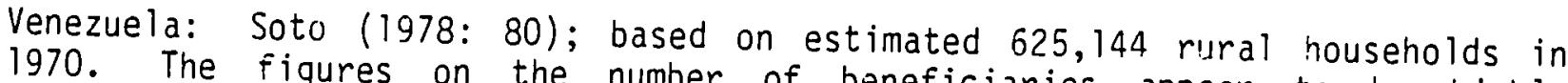
1970. The figures on the number of beneficiaries appear to be highly production cooperatives with 78,000 members. 95,000 . In 1968 there were 210

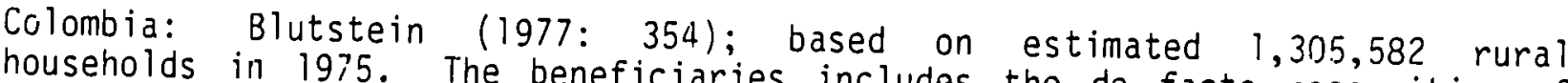
households in 1975. The beneficiaries includes the de facto recognition of squatters. Anaya (1976) reports a much lower figure for $1970,12,570$ were 1,284 empresas comuna to only $1.1 \%$ of rural households. In 1982, there Costa Rica: Barahona (1980: 275); based on estimated 214,516 rural households in 1975. Seligson (1980: 152) reports a much lower figure, 11,306 beneficiary families in 1976, representing onlj $5.3 \%$ of rural households in that year. In 1977, 17 production cooperatives were reported in existence with 517 members.

Honduras: Callejas (1983); Honduras (n.d.; 7); based on 428,516 rural households. In 1970, 133 empresas associativas were reported, with 10,000
members.

Dominican Republic: Weil (1973: 182); based on estimated 446,835 rural
households.

Chile: Cifuentes (1975); based on estimated 290,850 rural households.

Peru: Caballero and Alvarez (1980). The number of beneficiaries is a bit deceptive for over one-third of the beneficiaries enumerated in this estimate consist of households in the officially recognized peasant communities whose 971,392 rural households in 1975 .

Ecuddor: Franco-Garcia (1976: 49); based on estimated 716,447 rural households. Blankstein and Zuvekas (1973: 81 ) report that $88 \%$ of huasipungo households (engaged in feudal relations of production on large estates) became landowners through the reform. 
Nicaragua: The estimate includes 22,072 individuals that have recrived land either as individual holdings or as part of a production cooperative as of December, 1983, under the 1981 agrarian reform 1 aw, as well as 50,000 permanent workers on the state farms (Deere, Marchetti \& Reinhardt, 1984). The figure underestimates the total number of beneficiaries since it does not include those who have gained access to land through the reform but who have not yet received land titles. In 1983, there were an estimated 238,602 rural households.

El Salvador: The estimate includes 35,000 cooperative members on the Phase I estates and 39,936 applicants for individual land parcels under Decree 207 as of December 1983 (Deere, 1984). The figure probably overestimates the total number of beneficiaries since only 252 applicants under Decree 207 have actually received definitive land titles. The number of rural households in 1983 was estimated as 624,386 .

Data on the number of rural households was estimated from U.N. Demographic Yearbook (1979); 1977 Compendium of Social Statistics (U.N., 1980); America en $\frac{\text { Cifras }}{1981 .}$ O.A.S., 1977 ) and the 0.A.S. Statistical Bulletin, Vol. 3, no. 34, 
Table 2. Women in the Lat.in American Agrarian Reforms

\begin{tabular}{|c|c|c|}
\hline COUNTRY & $\begin{array}{l}\% \text { WOMEN } \\
\text { BENEF ICIAR IES }\end{array}$ & BENEF IC IARY CR I TER IA \\
\hline Mexico & n.d.* & $\begin{array}{l}\text { individuals over } 16 \text {; any age if have } \\
\text { dependent; men or women farmers }\end{array}$ \\
\hline Bolivia & n.d. & $\begin{array}{l}\text { individuals over } 18 \text { if feudatario; } \\
\text { over } 14 \text { if married; widows with } \\
\text { children may receive land }\end{array}$ \\
\hline Cuba & $(1983)$ & $\begin{array}{l}\text { individuals; state policy goal to } \\
\text { incorporate women }\end{array}$ \\
\hline Venezuela & n.d. & $\begin{array}{l}\text { individuals over } 18 \text {; preference to } \\
\text { household heads with most dependents \& } \\
\text { most efficient farmers }\end{array}$ \\
\hline Colomb :-: & n.d. & $\begin{array}{l}\text { individuals; point system favored } \\
\text { farming experience, education }\end{array}$ \\
\hline Costa Rica & n.d. & $\begin{array}{l}\text { individuals over 18; preference to } \\
\text { household heads with most dependents } \\
\text { and farming experience }\end{array}$ \\
\hline Hondura: & $\begin{array}{l}3.8 \% \\
(1979)\end{array}$ & $\begin{array}{l}16 \text { yrs. if single male; any age if } \\
\text { married male; single or widowed women } \\
\text { with children may apply }\end{array}$ \\
\hline Dominican Republic & n.d. & heads of household \\
\hline Ecuador & $n \cdot d$. & individuals \\
\hline Peru & n.d. & $\begin{array}{l}18 \text { yrs., heads of household with } \\
\text { dependent children, agriculturalists }\end{array}$ \\
\hline Chile & n.d. & $\begin{array}{l}18 \text { yrs. \& married or effective heads } \\
\text { of household; point system, favored } \\
\text { "aptitude" for agriculture }\end{array}$ \\
\hline Nicaragua & $\begin{array}{l}6 \% \\
(1982)\end{array}$ & $\begin{array}{l}\text { individual; an objective of agrarian } \\
\text { reform to incorporate women }\end{array}$ \\
\hline El Salvador & n.d. & individuals \\
\hline
\end{tabular}

$\star_{n} \cdot d .=$ no data available 
SOURCES FOR TABLE 2

Mexico: Anaya 1976: chpt. 9

Bolivia: Jemio 1973: 42 (Article 73 of A.R. Law)

Cuba: Collins, Benjamin, and Scott 1984: chpt. 13

Venezuela: Guerrero 1962 (Articles 104, 63 of A.R. Law)

Costa Rica: Escoto 1965: 11

Honduras: Callejas 1983; Honduras, 1976: 237-288 (Articles 97-125 of A.R. Law)

Dominican Republic: CEDEE 1983; Castro, Grullon and Leon 1983

Chile: Garrett 1982b

Ecuador: Redclift 1978

Peru: Deere 1982b (Article 84 of A.R. Law)

Nicaragua: CIERA 1984: chpt. 2

El Salvador: Simon, Stephens, and Diskin 1982, Appendix I 


\section{REFERENCES}

Alcerreca, $L$.

1974 Analisis Critico de la Ley Federal de Reforma Agraria. Mexico.

Anaya, $P$.

1976 Los Problemas del Campo. Mexico: Editorial Jus.

Barahona Riera, F.

1980 Reforma Agraria y Poder Politico, el Caso de Costa Rica. San

Benglesdorf, C. and A. Hageman.

1977 Emerging Frcm Underdevelopment: Women and Work in Cuba, in $Z$. Eisenstein (ed.), Capitalist Patriarchy and the Case for Socialist Feminism. New York: Monthly Review.

Blankstein, C.S. and C. Zuvekas, Jr.

1973 Agrarian Reform in Ecuador: An Evaluation of Past Efforts and the Development of a New Approach. Economic Development and Cultural Change 1(2): 73-94.

Blutstein, H.I., et al.

1977 Area Handbook for Colombia. Washington, D.C.: American

Bronstein, A.

1982 The Triple Struggle: Latin American Peassant Women. Boston:

Buchler, $P$.

1975 Agrarian Cooperatives in Peru. Berne: Sociological Institute.

Caballero, J.M. and E. Alvarez.

1980 Aspectos Cuantitativos de la Reforma Agraria (1969-79). Lima:

Callejas, R. Cecilia

1983 Examination of Factors Limiting the Organization of Rural Women in Honduras. M.A. Thesis, University of Florida.

Caro, E.

1982 Programas de Desarollo y la Participacion de la Mujer en Colombia, in M. Leon (ed.), La Realidad Colombiana. Bogota:
ACEP.

Castro, A., N. Grullon and M. Leon

1983 Instituto Agrario Dominicano. Report prepared for the Primer Seminario Nacional de Metodos y Tecnicas de Investigacion sobre la Mujer Rural, CIPAF. Santo Domingo. August. 
Castro, F.

1981 The Revolution within the Revolution, in E. Stone (ed.), Women and the Cuban Revolution. New York: Pathfinder Press.

CEDEE

1983 Historia y Situacion de la Organizacion de la Mujer Campesina en R.D. Paper presinted to the Segundo Encuentro Nacional de Educacion Popular, GEFAE. Santo Domingo. December.

Chambeu, $\mathrm{F}$.

1981 Participacion de la Mujer Rural en Acciones y Cambios Ideologicos en un Contexto de Reform Agraria. Lima: unpublished research

CIERA

1984 La Mujer en las Cooperativas Agropecuarias en Nicaragua.

Cifuentes, $E$.

1975 Land Reform in Chile. Background paper, Studies in Employment and Rural Developinent No. 15. International Bank for Reconstruction and Development. June.

Collins, J., M. Benjamin, and M. Scott

1984 No Free Lunch: Food and Revolution in Cuba Today. San Francisco: Institute for Food and Development Policy.

Colombia, Republica de

1984 Politica sobre el Papel de la Mujer Campesina en el Desarrollo Agropecuario. Departamento Nacional de Planeacion, mimeo. Mayo.

Croll, E.

1979 Socialist Development Experience: Women in Rural Production and Reproduction in the Soviet Union, China, Cuba, and Tanzania.

Discussion Paper. Institute of development Studies. September.

Deere, C.D.

1977 Changing Social Relations of Production and Peruvian Peasant Women's Work. Latin American Perspectives IV (1\&2).

1982a A Comparative Analysis of Agrarian Reform in El Salvador and Nicaragua. Development and Change Winter: 1-41.

1982b Rural Women and Agrarian Reform in Peru, Chile and Cuba. Paper presented to the Second Annual Women, Work, and Public Policy Workshop, Harvard University, April.

1983 Cooperative Development and Women's Participation in the Nicaraguan Agrarian Reform. American Journal of Agricultural Economics December. 
1984 Agrarian Reformi as Revolution and Counterrevolution: El Salvador and Nicaragua, in R. Burbach and P. Flynn (eds.), The Politics of Intervention. New York: Monthly Review.

Deere, C.D., and M. Leon de Leal

1982 Women in Andean Agriculture: Peasant Production and Rural Wage Employment in Colombia and Peru. Geneva: ILO.

Deere, C.D., P. Marchetti, and N. Reinhardt

1984 Agrarian Reform and the Transition in Nicaragua, 1979-1983. Conference, Harvard University, April.

de Janvry, A.

1983 The Agrarian Question and Reformism in Latin America.

Edwards, W.M.

1980 Ten Issues in Carrying out Land Reform in Colombia. Inter-America Economic Affairs 34(3): 55-68.

Engels, $F$. 1975 The Origins of Private Property, the Family and the State. New

Es ,oto, Leon

1965 Leyes de Reforma Agraria en America Central. Bogota: IICA-CIRA.

Fernandez, B.

1982 Reforma Agraria y Condicion Socio-Economica de la Mujer: El Caso de dos Cooperativas Agrarias de Producion Peruana, in M. Leon (ed.), Las Trabajadoras del Agro. Bogota: ACEP.

FMC (Federacion de Mujeres Cubanas)

1975 Memories: Second Congress of Cuban Women's Federation. La Habana: Editorial Orbit.

Franco Garcia, J.M.

1976 Nueva Ley de Reforma Agraria en el Ecuador. Derecho y Reforma Agraria Ano VII(7): 35-54.

Garrett, $P$.

1976 Some Structural Constraints on tiie Agricultural Activity of Women: The ChiTezn Hacienda. Madison: Land Tenure Center Paper No. 70, University of Wiscons in, December. 1982a Women and Agrarian Reform: Chile 1964-1973. Sociologia Ruralis
22(1): 17-28.

1982b La Reforma Agraria, Organizacion Popular, y Participacion de la Mujer en Chile, in M. Leon (ed.), Las Trabajadoras del Agro. 
Guerrero, T.

1962 La Cuestion Agraria. Caracas.

Honduras

1976 Ley de Reforma Agraria: Decreto Ley No. 170. Derecho y Reforma Agraria 7(7): 237-288.

n.d. Secretaria Tecnica del Consejo Superior de Planificacion Economica. Plan Nacional de Desarollo 1979-1983.

Iriarte, $G$.

1980 Sindicalismo Campesino Ayer, Hoy y Manana. La Paz: CIPCA.

Jemio, A.E.

1973 La Reforma Agraria en Bolivia. La Paz: MNR.

Leon, M. (ed.)

1982 Las Trabajadoras del Agro. Bogota: ACEP.

Lodono, A.

1975 Las Empresas Comunitarias Campesinas, Realidad y Perspectivas.

MacEwan, A.

1981 Revolution and Economic Development in Cuba. London: MacMillan.

Manzanilla, V.

1977 Reforma Agraria Mexicana. Mexico: Editorial Porrua.

McEwen, W.

1969 Changing Rural Bolivia. Research Institute for the Study of Man.

Mesa-Lago, C.

1972 The Labor Force, Employment, Unemployment and Underemployment in Cuba: 1899-1970. Beverly Hills: Sage Publications Professional Paper.

Organization of American States

1977 America en Cifras. Washington, D.C.: O.A.S.

1981 Statistical Bulletin 3(34). Washington, D.C.: O.A.S.

PPC, Comite Central del Partido Comunista de Cuba

1976 Sobre el Pleno Ejercicio de la Igualdad de la Mujer, Tesis y Resolucion. La Habana.

Redclift, M.R. 1978 Agrarian Reform and Peasant Organization on the Ecuadorian 
Safilios-Rothschild, C.

1983 Women and the Agrarian Reform in Honduras, in Land Reform: Land Settlement and Cooperatives. Rome: FAO jp. 15-24.

Seligson, $M$. 1980 Peasants of Costa Rica and the Development of Agrarian

Simon, L., J. Stephens and M. Disk in

1982 El Salvador Land Reform, Impact Audit. Boston: Oxfam America.

Soto, 0.D.

1978 La Empresa y la Reforma Agraria en la Agricultura Venezolana.

Stone, E. (ed.)

1976 Women and the Cuban Revolution. New York: Pathfinder Press.

United Nations

1979 United Nations Demoaraphic Yearbook 1979. New York: United

19801977 Compendium of Social Statistics. New York: Inited Nations. Urquidi, $A$

1971 Las Comunidades Indijenas, en Bolivia. Cochabamba: Editorial

Weil, T.E., et al.

1973 Area Handbook for the Dominican Republic. Washington, D.C.:

Youssef, N., and A. LeBel

1981 Exploring Alternative Employment and Income Generation Opportunities for Hondur an Women: Analys is and Recommendations. ICRW report to USAID/Honduras mission. October. 
The WOMEN IN INTERNATIONAL DEVELOPMENT PUBLICATION SERIES were founded in 1981 to disseininate information rapidly to national and international specialists in universities, government, and private institutions concerned with development issues affecting women. The two series, WORKING PAPERS ON WOMEN IN INTERNATIONAL DEVELOPMENT and the WID FORUM, publish reports of empirical studies and projects, theoretical analyses, and policy discussions that illuminate the processes of change in the broadest sense and encourage manuscripts that bridge the gap between research, policy, and practice. Publications in the series address women's historical and changing participation in economic, political, and religious spheres, intra- and inter-family role relationships, gender identity, women's health and health care, and the sexual division of labor.
EDITOR: Rita S. Gallin
MANAGING EDITOR: Pargaret Graham
EDITORIAL ASSOCIATE: Patricia Whittier
EDITORIAL BOARD: Maril, $n$ Aronoff, Sociology; Anne Ferguson, Anthro- pology; Ada Finifter, Political Science; Peter Glidhart, Family \& Child Ecology; John Hinnant, Anthro- pology; Susan Irwin, Anthropology; Akbar Mahdi, Soci- ology; Anne Meyering, History; Ann Millard, Anthro- pology; Nalini Malhotra Quraeshi, Sociology; Barbara Rylko-Bauer, Anthropology; Judith Stallmann, Agri- cultural Ecorinics; Paul Strassmann, Economics

NOTICE TO CONTRIBUTORS: To provide an opportunity for the work of those concerned with development issues affecting women to be critiqued and refined, all maruscripts submitted to the series are peer-reviewed. The review process averages two months and accepted manuscripts are published within five to six weeks. Authors receive ten free copies, retain copyrights to their works, and are encouraged to submit them to the journal of their choice.

Mariuscripts submitted should be double-spaced, sent in duplicate, and include the following: (1) title page bearing the name, address and institutional affiliation of the author; (2) one-paragraph abstract; (3) text; (4) notes; (5) references cited; and (6) tables and figures. The format of the article may follow any journal of the author's choice. Submit manuscripts to Rita Gallin, Editor, WID Publication Series, Office of WID, 202 International Center, Michigan State University, East Lansing, MI 48824-1035.

TO ORDER PUBLICATIONS: Publications are available at a nominal cost and cost-equivalent exchange relationships are encouraged. To order publications or receive a listing of them, write to Office of WID, 202 International Center, Michigan State University, East Lansing, MI 48824-1035, USA.

ACKNOWLEDGMENT: The Women in International Development Publication Series are partially funded by a Title XII Strengthening Grant.

MSU is an Affirmative Action/Equal Opportunity Institution 